archives

of thermodynamics

Vol. 36(2015), No. 3, 15-24

DOI: $10.1515 /$ aoter-2015-0019

\title{
Possibility of using adsorption refrigeration unit in district heating network
}

\author{
ANDRZEJ GRZEBIELEC \\ ARTUR RUSOWICZ \\ MACIEJ JAWORSKI \\ RAFAE LASKOWSKI
}

Institute of Heat Engineering, Warsaw University of Technology, Nowowiejska 21/25, 00-665 Warsaw, Poland

\begin{abstract}
Adsorption refrigeration systems are able to work with heat sources of temperature starting with $50^{\circ} \mathrm{C}$. The aim of the article is to determine whether in terms of technical and economic issues adsorption refrigeration equipment can work as elements that produce cold using hot water from the district heating network. For this purpose, examined was the work of the adsorption air conditioning equipment cooperating with drycooler, and the opportunities offered by the district heating network in Warsaw during the summer. It turns out that the efficiency of the adsorption device from the economic perspective is not sufficient for production of cold even during the transitional period. The main problem is not the low temperature of the water supply, but the large difference between the coefficients of performance, COPs, of adsorption device and a traditional compressor air conditioning unit. When outside air temperature is $25^{\circ} \mathrm{C}$, the $\mathrm{COP}$ of the compressor type reaches a value of 4.49 , whereas that of the adsorption device in the same conditions is 0.14 . The ratio of the COPs is 32. At the same time ratio between the price of $1 \mathrm{kWh}$ of electric power and $1 \mathrm{kWh}$ of heat is only 2.85. Adsorption refrigeration equipment to be able to compete with compressor devices, should feature $C O P_{a d s}$ efficiency to be greater than 1.52. At such a low driving temperature and even changing the drycooler into the evaporative cooler it is not currently possible to achieve.
\end{abstract}

Keywords: Refrigeration; Adsorption refrigeration; Air conditioning; District heating network

\footnotetext{
${ }^{1}$ Corresponding Author. E-mail: angrzeb@itc.pw.edu.pl
} 


\section{Nomenclature}

$$
\begin{aligned}
& \text { c } \quad-\quad \text { specific heat, } \mathrm{J} / \mathrm{kg} \mathrm{K} \\
& \mathrm{COP}-\text { coefficient of performance } \\
& k-\text { costs, } \mathrm{PLN} / \mathrm{kWh} \\
& \dot{m} \quad-\quad \text { mass flow, } \mathrm{kg} / \mathrm{s} \\
& N \quad-\quad \text { electric power, } \mathrm{kW} \\
& \dot{Q} \quad-\quad \text { heat capacity, } \mathrm{kW} \\
& T \text { - temperature, }{ }^{\circ} \mathrm{C}
\end{aligned}
$$

\section{Subscripts}

$\begin{array}{lll}\text { ads } & - & \text { adsorption } \\ c & - & \text { compressor } \\ C & - & \text { cold } \\ e & - & \text { evaporating } \\ e l & - & \text { electricity } \\ h & - & \text { heat } \\ H S & - & \text { heat source } \\ \text { in } & - & \text { inlet } \\ \text { out } & - & \text { outlet } \\ p & - & \text { constant pressure }\end{array}$

\section{Introduction}

Due to legal restrictions associated with using traditional refrigerants, refrigeration and air-conditioning industry is looking for both new refrigerants, and new technical solutions $[1,2,10]$. One such solution is the adsorption refrigerating, since the working fluid in them is mostly water or methanol [12].

Development of adsorption refrigeration devices is associated with an attempt to use of waste heat $[3,5,6,8]$. In the first phase of their appearance on the market, adsorption units compete primarily with the absorption devices, but unfortunately their efficiency is lower than the absorption device. In addition, the specificity of action (operation in cycles) meant that the use of adsorption devices was very limited. Technological developments allow adsorption devices to operate at driving temperatures starting at $50{ }^{\circ} \mathrm{C}$ [9]. This is the niche in which these devices can be successfully developed. It should be recalled that absorption refrigeration systems require the heat source was at a temperature above $90^{\circ} \mathrm{C}$. In recent years the development of adsorption refrigeration is associated with solar energy and the use of facilities in district heating networks.

In the case of solar energy it is a matter related to the so-called solar cooling. Adsorption units are powered by solar collectors, producing cooling 
power mostly for air conditioning [4,16]. It is the ideal solution in terms of matching resource supply and demand. The greater the intensity of solar radiation, the greater the demand for air conditioning purposes. In Fig. 1. was presented a schematic diagram of the use of adsorption refrigeration device inside solar cooling system.

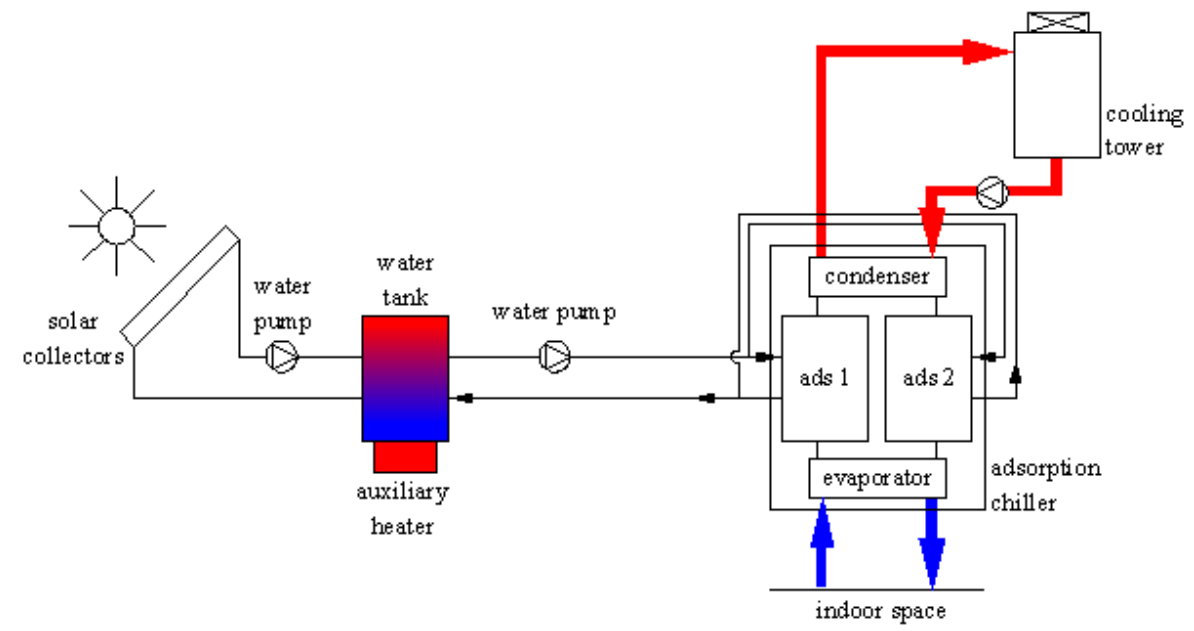

Figure 1: Adsorption solar cooling system.

There are three possible technical solutions for using adsorption refrigeration devices in trigeneration systems [7]:

- decentralized system,

- centralized system with decentralized cold generation,

- centralized system.

In a decentralized system production of heat, cooling and electricity takes place directly at the customer, and any surplus electricity is sold to the grid. The centralized system with decentralized production of cold, works in this way, that electricity and heat are generated at the power plant, and sorption devices utilize the heat from district network. The centralized system for electricity, heat and cold are produced at the plant. Products such as heating or cooling are supplied by pipelines to individual customers. Due to the fact that, in a decentralized system and a centralized one, adsorption device can be directly driven by combustion of fuel unrivaled better solution is to use the absorption unit. In the case of a centralized system with 
distributed production of cold only possible solution is the use of adsorption devices. This is due to the fact that the greatest demand for cooling power occures in the summer, and then in the district heating water is the lowest temperature. The temperature drops to $72{ }^{\circ} \mathrm{C}$.

\section{Methodology}

In the previous chapter it was mentioned that the only sensible use of adsorption equipment in trigeneration systems is the use of this device, in a centralized system with distributed production of cold. This solution has several advantages:

- does not require building a system of pipes to distribute cold to customers,

- compared with a distributed system does not need to supply fuel to individual customers.

Technical and economic analysis of the proposed solution will be based on determining how much cold can be generated based on heat from district heating network. For this purpose are examined the adsorption refrigerating appliance as a function of the supply water temperature and outside air temperature. A further order will be subject to economic analysis in comparison to a standard compressor air-conditioning. For the analysis will be adopted water temperature in the district heating network as shown in Fig. 2. These are the parameters of the district heating network in Warsaw $[13,15]$.

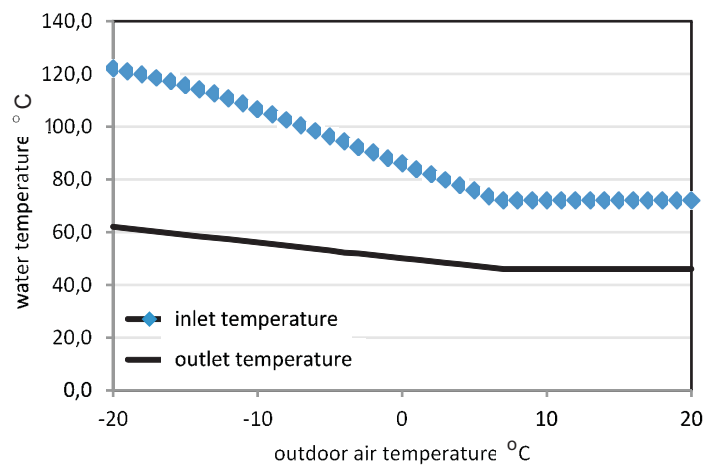

Figure 2: Temperature parameters in the district heating network in Warsaw. 
For the purposes of economic analysis there was used a compressor system with refrigerant R410A operating with a nominal cooling capacity of $\dot{Q}_{e}=$ $10 \mathrm{~kW}$. The basic parameters of the compressor refrigeration units are: evaporating temperature $T_{e}=5^{\circ} \mathrm{C}$, superheating $9 \mathrm{~K}$, subcooling $4 \mathrm{~K}$ and isentropic efficiency of the compressor $66 \%$. The main objective of economic analysis is to determine which device produces the cold cheaper under the same conditions [14].

\subsection{Media prices}

In accordance with current tariffs in Warsaw, the economic analysis will be adopted with the following values. The price of $1 \mathrm{kWh}$ of electricity is $0.53 \mathrm{PLN}$, and the price of $1 \mathrm{kWh}$ of heat from district heating network amounts to 0.186 PLN (0.175 PLN per kWh - variable costs, 0.011 PLN per $\mathrm{kWh}$ - fixed costs). Cost of heat was calculated for building with 0.5 MW heat demand and current operator prices for tariff group A3B1C211 [17].

\section{$3 \quad$ Experimental studies}

Experimental research has been made on adsorption device with a nominal cooling capacity of $10 \mathrm{~kW}$. Electric power consumption by the circulation pumps is up to $N=0.410 \mathrm{~W}$. The device consists of three circuits. Supply circuit, the cooling circuit, and circuit which rejects heat to environment. Power circuit should be heated with district heating network. For the sake of experiment the supply circuit is connected to the heating elements of the regulated power $25 \mathrm{~kW}$. The aim is to simulate district heating system work by heaters. The parameters of the refrigeration cycle were set to $12{ }^{\circ} \mathrm{C} / 7^{\circ} \mathrm{C}$ - that is a standard in the water air conditioning systems, where the water flows into chiller with a temperature of $12^{\circ} \mathrm{C}$ and flows back at a temperature of $7^{\circ} \mathrm{C}$ [11]. Another circuit, is the circuit rejecting heat. The water temperature in this circuit depends on the outdoor air temperature. In Fig. 4 is presented a schematic of circuits cooperating with the adsorption device in the experimental apparatus.

According to Fig. 2 the temperature in the periods in which air conditioning is used, the supply water temperature in district heating network is $72^{\circ} \mathrm{C}$. From that fact we can expect that driving temperature in heat source circuits (Fig. 3) can be up to $65^{\circ} \mathrm{C}$. For such a temperature the experimental study was carried out. For such parameters have been relevant 


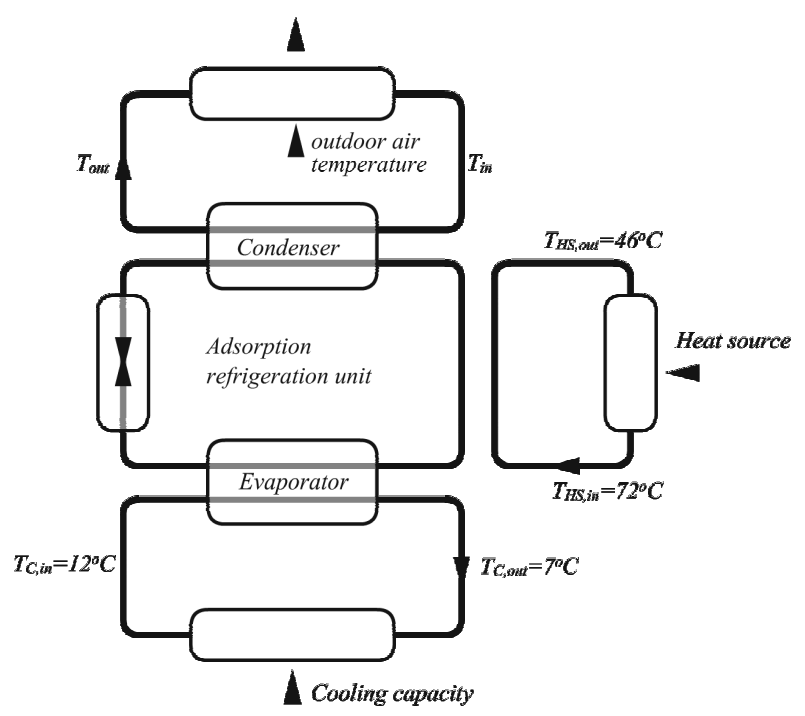

Figure 3: Experimental apparatus.

quantities and the measured values were obtained of rates of heat capacity in every circuits according to the equation

$$
\dot{Q}=c_{p} \dot{m}\left(T_{\text {out }}-T_{\text {in }}\right),
$$

where $\dot{Q}$ is the rate of heat in circuits, $c_{p}$ - specific heat of water, for different temperatures, $\dot{m}$ - mass flow of water, $T_{\text {out }}$ and $T_{\text {in }}$ are the measured temperatures respectively at outlet and inlet to heat exchanger. Thermal balance measurements were carried out in all three circuits. In order to determine the instantaneous coefficient of performance $C O P_{a d s}$ for the adsorption device the formula was applied:

$$
C O P_{a d s}=\frac{\dot{Q}_{c}}{\dot{Q}_{H S}}
$$

where $\dot{Q}_{c}$ is the cooling rate of heat and $\dot{Q}_{H S}$ is heat source. In Fig. 4 was presented measured adsorption unit cooling capacity compared to the compressor device for the variable outside air temperature. When the outdoor air temperature increases to $30^{\circ} \mathrm{C}$, the adsorption device stops to work. In Fig. 5 there was presented the calculated coefficient of performance $C O P_{a d s}$ according to Eq. (2), based on measurement of cooling rate of heat $\dot{Q}_{C}$ and heat source rate of heat $\dot{Q}_{H S}$. 


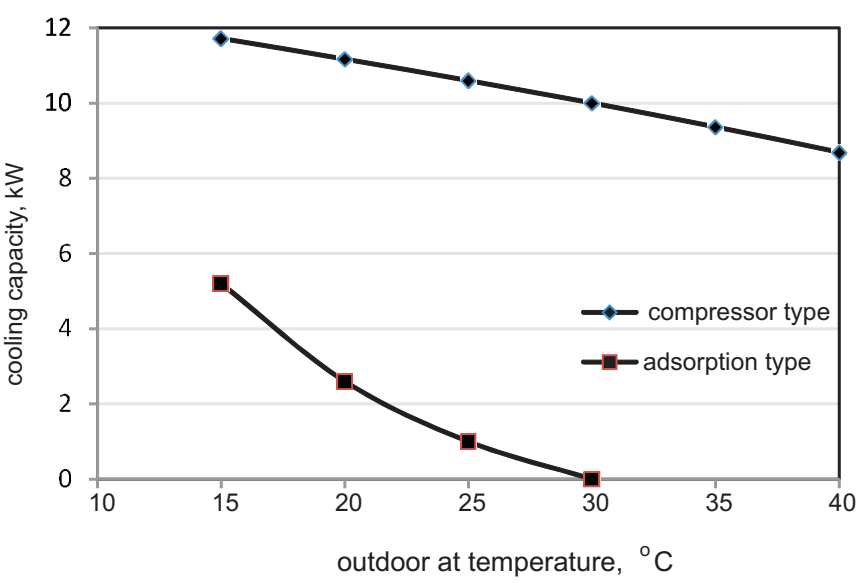

Figure 4: Cooling capacity for different device types.

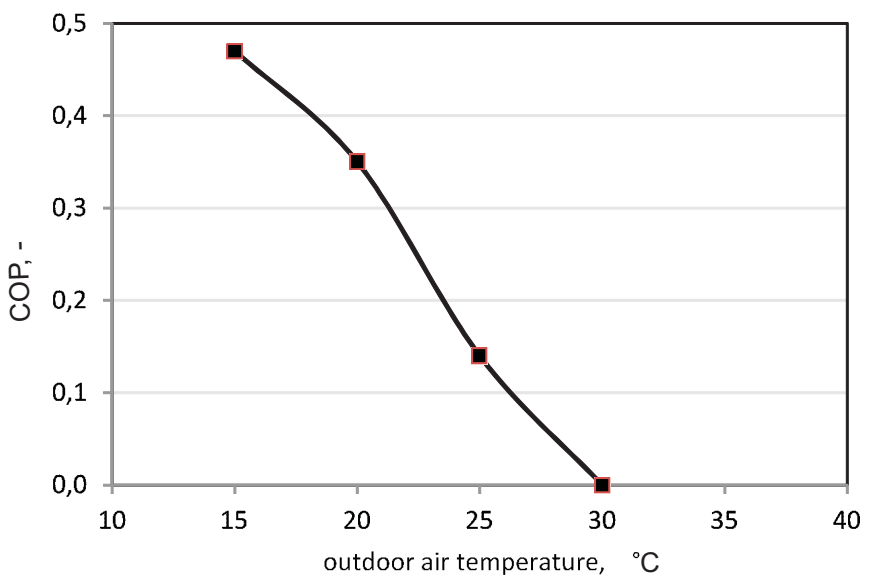

Figure 5: Coefficient of performance for adsorption refrigeration unit.

\section{The costs of generation $1 \mathrm{kWh}$ of cold}

In the case of a compressor device the cost of production $k_{c}$ per $1 \mathrm{kWh}$ of cold is only electrical power needed to drive the compressor and the fan of the condenser, whereas in the case of the adsorption device the cost of production $k_{a d s}$ per $1 \mathrm{kWh}$ cold is electric power consumed to drive the circulation pumps, fans as well as it reflects the heat to the ambient air 
circulation and heat for driving the device. Figure 6 presents comparison of the cost of production of $1 \mathrm{kWh}$ of cold from the adsorption unit and a compressor for various outdoor air temperatures. For the adsorption device was calculated the total cost containing fixed and variable costs for contracted heat power of $0.5 \mathrm{MW}$. In the entire operating range adsorption unit cost of production of cold is from a few to several times greater than using a compressor unit.

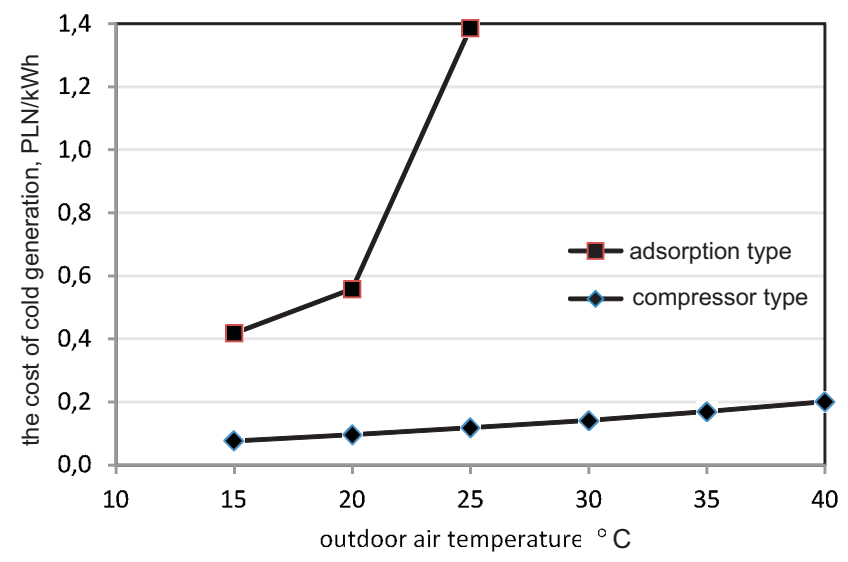

Figure 6: Costs of generation $1 \mathrm{kWh}$ of cold for different device types.

In Fig. 7 was presented the shares of electricity and heat in the balance sheet total production cost of $1 \mathrm{kWh}$ cold for the adsorption device.

Characteristics shown in Fig. 7 is due to the fact that the work of adsorption device is periodic, which increases when outside air temperature increases which subsequently changes the potential heat is released into the environment, and thus prolongs the process of desorption and adsorption occurring in adsorption beds. The consequence of this is smaller water flows through all circuits. On the other hand, due to the fact that decreases the coefficient of performance $C O P_{a d s}$ increase the consumption of driving heat.

\section{Conclusions}

Adsorption units are able to utilize heat from the district heating network. Coefficient of thermal efficiency may reach a value of more than 0.45 when the outside air temperature drops below $15^{\circ} \mathrm{C}$. It is arguable whether at 


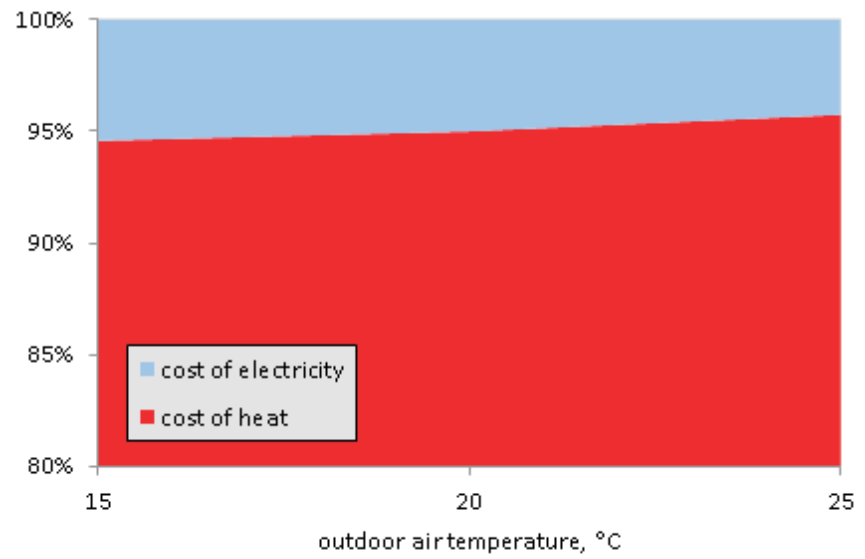

Figure 7: The share of heat and electricity in the cost structure.

these temperatures air conditioning in buildings is required. That could only be justified in office buildings or data centers, where air conditioning systems are an integral part. So from a technical point of view there is no problem to drive the adsorption refrigerating utilising heat from the district heating network. However, from an economic point of view production of $1 \mathrm{kWh}$ of cold at an outdoor temperature of $+15{ }^{\circ} \mathrm{C}$ is 5.3 times more expensive, and at an outdoor temperature of $+25^{\circ} \mathrm{C}$ is 11.4 times more expensive than generating cold from the compressor unit. The use of evaporative coolers rather than drycoolers certainly would positively affect the efficiency of the device and economic balance, but even in this solution generation cooling from compressor devices would be cheaper. Due to the price structure and the efficiency of adsorption units adsorption devices should not be used at the moment in combination with district heating network. However, in other applications, where price of heat is lower, adsorption refrigeration equipment can be successfully used.

Received 9 November 2015

\section{References}

[1] Bohdal T., Charun H., Sikora M.: Selected aspects of legal, technical and ecological use of compression heat pumps. Rocznik ochrona środowiska 17(2015), 1, 461-484. (in Polish). 
A. Grzebielec, A. Rusowicz, M. Jaworski and R. Laskowski

[2] Butrymowicz D., Smiercew K., Karwacki J., Gagan J.: Experimental investigations of low-temperature driven ejection refrigeration cycle operating with isobutane. Int. J. Refrig. 39(2013), 196-209, DOI: 10.1016/j.ijrefrig.2013.10.008.

[3] Cacciola G., Restuccia G.: Reversible adsorption heat pump: A thermodynamic model. Int. J. Refrig. 18(1995), 2, 100-06.

[4] Chwieduk D., Grzebielec A., Rusowicz A.: Solar cooling in buildings. Tech. Trans. Civil Eng. 111(2014), 3-B, 65-73.

[5] Cyklis P., Kantor R.: Concept of ecological hybrid compression-sorption refrigerating systems. Tech. Trans. Mechanics 109(2012), 5, 31-40.

[6] Grzebielec A., Kosiński T., Wereszczyński R.: Modern constructions of adsorption refrigeration systems in use. Chłodnictwo 47(2012), 12, 28-30. (in Polish)

[7] Grzebielec A., Rusowicz A.: Analysis of the use of adsorption processes in trigeneration systems. Arch. Thermodyn. 34(2013),4, 35-49, DOI: 10.2478/aoter2013-0028.

[8] Grzebielec A., Rusowicz A., Ruciński A.: Use of the methanol-activated carbon sorption set in a refrigeration unit. Przemysł Chemiczny 94(2015), 952-955, DOI:10.15199/62.2015.6.18. (in Polish).

[9] Gwadera M., Kupiec K.: Adsorption refrigeration systems. Inż. Ap. Chem. 50(2011), 5, 38-39 (in Polish).

[10] Igliński B., Buczkowski R., Iglińska A., Cichosz M., Plaskacz-Dziuba M.: SWOT analysis of the renewable energy sector in Poland. Case study of Wielkopolskie region. J. Power Technol. 95(2015), 2, 143-157.

[11] JAWORSKI M.: Thermal performance of building element containing phase change material (PCM) integrated with ventilation system - An experimental study. Appl. Therm. Eng. 70(2014), 1, 665-674, DOI: 10.1016/j.applthermaleng.2014.05.093.

[12] Kupiec K., Gwadera M., Larwa B.: Adsorption in perfect mixing tank - comparison of exact and approximate kinetic models. Chem. Process Eng. 35(2014), 3, 277-291, DOI: 10.2478/cpe-2014-0021.

[13] Milewski J., SzabŁowski Ł., Bujalski W.: Identification of the objective function for optimization of a seasonal thermal energy storage system. Arch. Thermodyn. 35(2014), 4, 69-81.

[14] Skorek-Osikowska A., Bartela Ł., Kotowicz J.: A comparative thermodynamic, economic and risk analysis concerning implementation of oxy-combustion power plants integrated with cryogenic and hybrid air separation units. Energ. Convers. Manage. 92(2015), 421-430, DOI: 10.1016/j.enconman.2014.12.079.

[15] Smyk A., Pietrzyk S.: Heat losses of the district heating network during different operational conditions. Rynek Energii 103(2012), 6, 46-51.

[16] Torres Ledesma J., Łapka P., Domański R., Casares F.S.: Numerical simulation of the solar thermal energy storage system for domestic hot water supply located in south Spain. Therm. Sci. 17(2013), 2, 431-442, DOI: 10.2298/TSCI111216050L

[17] VEOLIA: Veolia Energia Warszawa S.A. price list for 15.08.2015 (in Polish). 